\title{
Оцінка енергетичних характеристик квантово-оптичних засобів контролю вмісту викидів вихлопних газів автомобілів
}

\author{
В.А. Романюк ${ }^{1}$, С.О. Стародубцев ${ }^{1}$, А.А. Савін ${ }^{1}$, І.А. Черепньов ${ }^{2}$ \\ ${ }^{1}$ Національна академія Національної гвардії України \\ email: roman_r58@ukr.net \\ ${ }^{2}$ Харківський національний технічний університет сільського господарства \\ імені Петра Василенко (м. Харків, Україна)
}

\begin{abstract}
Проведено аналіз теоретичних основ лазерних вимірювань складу повітряного середовища та можливості його застосування в надзвичайних ситуаціях, спричинених викидами у великій кількості забруднюючих газів, аерозолів і мікрочастинок дизельними двигунами, двигунами внутрішнього згоряння автомобільного транспорту. Запропоновано метод розв'язання задачі оперативного моніторингу складу газів домішок і аерозолів в зоні контролю застосуванням єдиного комплексу лазерної вимірювальної апаратури.

Найбільш перспективним методом діагностики забруднень повітря є дистанційні методи зондування. Серед дистанційних методів особливе місце займають лазерні методи. Одним з найефективніших засобів дистанційного моніторингу ступеня забруднення навколишнього середовища $€$ лазерні монітори, звані також як лідари (по аналогії з радарами).

Методи зондування поділяються, в залежності від способу отримання інформації на: активні - при цьому об'єкти навколишнього середовища зондуються електромагнітним випромінюванням і пасивні, інформація отримується шляхом реєстрації результату взаємодії випромінювання природних джерел або власне випромінювання аналізованих домішок.

У статті розглянута можливість застосування лазерних засобів для оперативного контролю ступеню забрудненості навколишнього повітря вихлопами автомобільних двигунів. Приведені оцінки енергетичних параметрів лідару для виявлення типових забруднюючих компонентів.
\end{abstract}

Ключові слова: лазер, атмосфера, оперативний моніторине.

Актуальність роботи. Проблема забруднення повітря відпрацьованими газами автомобілів є глобальною. У всьому світі кількість автомобілів із кожним днем збільшується у геометричній прогресії, що не може не позначитися на рівні забруднення довкілля, а особливо атмосферного повітря, вихлопними газами. Транспортно-дорожній комплекс вважається одним з найбільших джерел забруднення навколишнього середовища (шумове та теплове забруднення $€$ найбільш поширеними). Все більше і більше людей мають власні авто. Це не може не позначитись на якості повітря, а особливо в густонаселених мегаполісах, де скупчення автомобілів набагато вище за приміські зони. В Україні також спостерігається стабільне зростання кількості автомобільного транспорту, незважаючи на кризові явища та тенденцію до зменшення кількості населення. Це призводить до перевантаження дорожньої мережі міст і загострює соціальноекономічні, санітарно-гігієнічні і технічні проблеми, пов'язані із здоров'ям людей та організацією дорожнього руху.

Вихлопні гази (або відпрацьовані гази) - основне джерело токсичних речовин двигуна внутрішнього згоряння - це неоднорідна суміш різних газоподібних речовин з різноманітними хімічними і фрізичними властивостями, що складається з продуктів повного і неповного згоряння палива, надлишкового повітря, аерозолів і різних мікродомішок (як газоподібних, так і у вигляді рідких і твердих частинок), що надходять 3 циліндрів двигунів в його випускну систему. У своєму складі вони містять близько 300 речовин, більшість з яких токсичні.

Основними нормованими токсичними компонентами вихлопних газів двигунів $€$ оксиди вуглецю, азоту та вуглеводнів. Крім того, з вихлопними газами в атмосферу надходять граничні і ненасичені вуглеводні, альдегіди, канцерогенні речовини, сажа та інші компоненти.

Приблизний склад вихлопних газів двигунів представлено в таблиці 1.

На перший погляд, відмінність між локальними і дистанційними методами, які використовують одні і ті ж механізми взаємодії випромінювання з речовиною, мінімальна, і єдиною відмінністю $€$ так зване «завдання поширення» зондуючого і інформаційного потоків випромінювання в атмосфрері з заданими параметрами. 
Таблиця 1. Компоненти вихлопних газів

\begin{tabular}{|c|c|c|c|}
\hline \multirow{3}{*}{$\begin{array}{c}\text { Компоненти вих- } \\
\text { лопного газу }\end{array}$} & \multirow{2}{*}{\multicolumn{2}{|c|}{$\frac{\text { Вміст за обсягом,\% }}{\text { Двигун }}$}} & \multirow{3}{*}{ 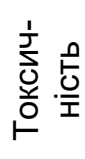 } \\
\hline & & & \\
\hline & Бензин & Дизель & \\
\hline Азот & $74,0-77,0$ & $76,0-78,0$ & $\mathrm{Hi}$ \\
\hline Кисень & $0,3-8,0$ & $2,0-18,0$ & $\mathrm{Hi}$ \\
\hline Пари води & $3,0-5,5$ & $0,5-4,0$ & $\mathrm{Hi}$ \\
\hline Діоксид вуглецюю & $5,0-12,0$ & $1,0-10,0$ & $\mathrm{Hi}$ \\
\hline Оксид вуглецю & $0,1-10,0$ & $0,01-5,0$ & Так \\
\hline $\begin{array}{l}\text { Вуглеводні } \\
\text { некарцерогенні }\end{array}$ & 0 & 0 & $\mathrm{~T}$ \\
\hline Альдегіди & $0-02$ & $0,001-0,009$ & Так \\
\hline Оксид сірки & $0-0,002$ & $0-0,03$ & Так \\
\hline Сажа $/ \mathrm{M}^{3}$ & $0-0,04$ & $0,01-1,1$ & Так \\
\hline $\begin{array}{l}\text { Бензопірен } \\
\text { мr/M }\end{array}$ & $0,01-0,02$ & до 0,01 & $\mathrm{Ta}$ \\
\hline
\end{tabular}

У той же час, дистанційні методи дозволяють вирішувати ряд абсолютно унікальних завдань моніторингу навколишнього середовища і в ряді випадків $є$ абсолютно незамінними. У такій ситуації дистанційні методи і засоби моніторингу параметрів газів, аерозольних викидів і скупчень фрагментів і мікрочастинок $є$ єдиний надійний і практично безпечний для персоналу метод вимірювання. Найбільш яскраво виражена специфіка дистанційній методів і засобів полягає у використанні направлених потоків випромінювання для отримання і перенесення корисної інформації.

Одним з найбільш перспективних напрямків дистанційного моніторингу об'єктів навколишнього середовища $€$ використання спектральних методів аналізу в УФ, видимому, 14 і НВЧ областях спектра. Аналіз різних НС (природні катаклізми, техногенні катастрофи, теракти і ін.), що мали місце в світі за останні 10-15 років, показав, що особливо небезпечні газові і аерозольні викиди відносяться в основному до речовин зі складною молекулярною структурою. Тут можуть використовуватися потоки випромінювання як природного походження (тоді засоби і методи називають пасивними), так і спеціально створювані високо направлені потоки випромінювання для реалізації процесу дистанційного зондування - в цьому випадку мова йде про активні системи і методи зондування [2].

Можна таким чином класифікувати методи зондування (локації): - активна локація - це локація, при якій об'єкти навколишнього середовища зондуються електромагнітним випромінюванням і реєструються ефекти його взаємодії з газовими, аерозольними домішками. Ці ефекти розрізняють за такими видами фрізичних явищ: 1) зворотне пружне розсіяння (молекулярне або аерозольна); 2) зворотне не пружне розсіювання (комбінаційне розсіювання світла і люмінесценція) і перевипромінювання (вторинне 14 - випромінювання); 3) диференціальне поглинання і розсіювання.

Пасивна локація - це локація, при якій реєструються ефекти взаємодії електромагнітного випромінювання природних джерел з домішками хімічної природи або власне випромінювання аналізованих домішок на трасі спостереження.

Активні засоби дистанційного зондування

Активні дистанційні засоби зондування атмосфери засновані на використанні лазерів 3 довжинами хвиль від УФ до ІЧ-діапазону і джерел мікрохвильового випромінювання. При цьому використовуються дані за різними типами спектрів молекул, пов'язаних 3 електронним поглинанням, комбінаційною розсіюванням (КР) і люмінесценцією в УФ і видимому діапазонах, 14 поглинанням на основних, складових переходах i обертони, поглинанням на обертальних переходах і т.д. Аналіз спектрів домішок показує, що через великий розкид спектральних параметрів виявляється важко вибрати універсальний тип лазерного локатора або спектрорадіометра для виявлення всієї гами забруднювачів з однаково низькими межами виявлення і високу селективність. У лазерних системах, що працюють в режимі прийому зворотного сигналу, використовуються в основному лазери та інші джерела УФ, видимого, ІЧ і СВЧ діапазонів. Багаточастотні лазери використовуються для роботи в режимі диференціального поглинання 3 відображенням сигналів від катафотів або топографічних об'єктів і диференціального розсіювання при відбиванні від аерозолів $[3,4,6]$.

Аналіз останніх досліджень і публікацій.

Стрімкий розвиток усіх галузей промисловості, енергетики, транспорту, збільшення чисельності населення, урбанізація та хімізація всіх середовищ діяльності людини призводять до порушення і забруднення біосфери, її окремих компонентів. Екологічна ситуація, що склалася в ряді промислових центрів, в районах видобутку та переробки мінеральної сировини, будівництва та експлуатації промислових об'єктів, часто близька до критичної $[1,7]$. Можливість серйозних негативних наслідків забруднення навколишнього середовища джерелами різного походження, в тому числі продуктами згоряння палив автомобільних двигунів, обумовлює пошуки вирішення екологічної проблеми і підтримки природного балансу різних складових атмосфери. У зв'язку з цим останнім часом розширилися дослідження з розробки методів контролю стану навколишнього середовища.

Особлива увага при цьому приділяється методам безконтактного визначення параметрів середовища, які забезпечують можливість отримання необхідних даних 3 високою оперативні- 
стю і в значних просторових масштабах. Крім того, в більшості випадків безпосередній доступ до місць, що піддаються дослідженню, надзвичайно ускладнений, що викликає необхідність використання методів дистанційного контролю вмісту забруднюючих речовин у повітрі [2].

Суть методики коротко полягає в наступному.

Забруднена атмосфера містить непритаманні їй гази (двоокис сірки - $\mathrm{SO}_{2}$, оксиди азоту $\mathrm{NO}$ i NO${ }_{2}$, вуглеводні - $\mathrm{H}_{\mathrm{x}} \mathrm{C}_{\mathrm{x}}$ і інші), продукти їх реакції типу кислот і окислювачів, а також тверді пилинки з розмірами $10^{-8}$ до $10^{-3}$ м (аерозолі). На цьому базуються методи лазерного моніторингу забруднень в атмосфері.

Мета екологічного моніторингу - інформаційне забезпечення управління природоохоронною діяльністю і екологічною безпекою.

Для досягнення поставленої мети необхідно дати відповіді на наступні питання:

- який стан природного середовища в розглянутий відрізок часу в порівнянні з попереднім і які зміни (позитивні, негативні) очікуються в природному середовищу в прогнозований відрізок часу;

- в чому причини змін, що відбулися і можливих змін в майбутньому (в тому числі небажаних, згубних, критичних) і що стало, $\epsilon$ або буде джерелом цих змін (як правило, шкідливих техногенних впливів);

- які дії на дане локальне природне середовище, що визначаються виходячи з виробленої для даного випадку критеріальної основи оцінок функції корисності - шкідливості, є шкідливими (небажаними або неприпустимими);

- який рівень техногенних впливів, в тому числі в сукупності з природними або стихійними процесами і діями, що відбуваються в даному природному середовищі, є допустимим для природного середовища і окремих іiї компонентів або комплексів (ценозів) і які резерви є у природного середовища для саморегенерації стану, адекватного вихідного, прийнятому за стан екологічного балансу;

- який рівень техногенних впливів на природне середовище, окремі її компоненти і комплекси є неприпустимим або критичним, після якого відновлення природного середовища до рівня екологічного балансу $є$ нездійсненним [1].

\section{Головна частина}

Як показують численні дослідження [2,5], найбільшими концентраціями забруднюючих викидів автомобільних двигунів мають газові компоненти СО, водневмісні сполуки $\mathrm{CmHn}$, азотовмісні сполуки NOx і тверді частинки вуглецю.

Значення фонової концентрації даних компонент в атмоссрері в залежності від різних кліматичних умов і місцевості відомі з достатнім ступенем точності. Порівнюючи результати дистанційного зондування змісту викидів за допомогою лідарних засобів зі значенням фонових концентрації даних компонент можна судити про стан загальної екологічної обстановки в районі дослідження і оперативно вживати заходів щодо ії поліпшення. Найбільш чутливим методом вимірювання поточної концентрації складових викидів $€$ метод диференційного поглинання і розсіювання лазерного випромінювання молекулами речовини досліджуваної компоненти [1].

Для лазера з широкою смугою випромінювання, центр якої відповідає довжині хвилі $\lambda_{\text {o }}$ рівняння лазерного дистанційного зондування має вигляд [5, 7]

$$
\begin{gathered}
E\left(\lambda_{0}, R\right)=\frac{c \tau A \xi(R)}{2 R} \times \\
\times \int_{\lambda-\Delta_{c}}^{\lambda+\Delta_{c}} \exp \left(-\int_{0}^{R}\left[N_{\phi} \sigma+K(\lambda)\right] d R\right) \times \\
\times \xi(\lambda, R) \beta(\lambda, R) E_{L}(\lambda) d \lambda
\end{gathered}
$$

де $E_{L}(\lambda)=\int E(\lambda) d \lambda$ - спектральна щільність випромінюваної енергії, розподілена за нормальним законом; $\Delta_{c}-$ вікно пропускання приймальні оптичної системи; $\xi(\lambda$,$) - коефіціент спектраль-$ ного пропускання приймальні оптичної системи; $\tau$ - тривалість зондуючого імпульсу; $\xi(R)$ - геометричнй форм-фактор; $\sigma_{n}=\int \sigma(\lambda) d \lambda$ - спектральний розподіл перетину поглинання, що описується для вихлопних газів лоренцівским контуром; $A$ - площа приймальної апертури; $\beta(\lambda, R)$ - об'ємний коефіцієнт зворотного розсіювання; $N_{\phi}$ - фонова концентрація досліджуваного газу на трасі випромінювання; $K_{\text {роз }}(\lambda)-$ коефіцієнт розсіювання випромінювання;

Для прийняття рішення про виявлення досліджуваної компоненти, необхідно виконання умови

$$
E_{\text {вим }}(\lambda, R)>E_{\text {пор }}(\lambda)
$$

де

$$
E_{\text {пор }}(\lambda)=\frac{1}{D^{*}}\left[\frac{F g A d}{4 B \xi_{e}}\right]^{1 / 2} q
$$

мінімальна енергія, яка детектується для фотодетектора, для умов обмеження тепловим струмом; $D^{*}$ - здатність виявлення детектора; $B=1 / 2 \tau$ - ширина смуги детектування; $A d$ - площа детектора; $\xi_{e}$ - збірна здатність електростатичного фокусування; $F g$ - параметр посилення шуму; $q$ - відношення сигнал / шум;

Рішення рівняння (1), з урахуванням (2) і (3), дає вираз для мінімальної вихідної енергії лазеру з урахуванням поглинання фонової складової газу на трасі $N_{\phi}$ і лоренцовського контуру лінії поглинання в сліді вихлопу автомобіля. 


$$
\begin{gathered}
E_{\min }=\frac{2(R+\Delta R)^{2}}{\beta\left(\lambda_{0}, R+\Delta R\right) A c \tau D^{*}} \times \\
\times \exp \left(2 \int_{0}^{R} N \sigma+K(\lambda) d R\right) \times \frac{q}{\left(4 B \xi e / F_{G} A_{d}\right)^{\frac{1}{2}}} \times \\
\times \int_{\lambda-\Delta_{c}}^{\lambda+\Delta_{c}} \exp \left\{\begin{array}{c}
-\frac{\left(\lambda+\lambda_{0}\right)^{2}}{\Delta_{n}^{2}+\Delta_{x}^{2}}- \\
-\frac{2 \tau_{1} \Delta_{0}}{\Delta_{x}\left[\left(\lambda+\lambda_{0}\right)^{2}+\Delta_{n}^{2}\right]}
\end{array}\right\} d \lambda
\end{gathered}
$$

де $\Delta_{0}$ - напівширина лінії лазерного випромінювання; $\Delta_{n}$ - напівширина лінії поглинання досліджуваного газу;

$$
\tau_{1}=\int N \sigma^{\lambda} d \lambda
$$

$\tau_{1}$ - оптична товщина поглинання газу;

$$
\Delta_{x}=\frac{\Delta_{0}}{\Delta_{n}}
$$

$\sigma^{\lambda}$ - спектральний розподіл лінії поглинання;

Залежність енергії випромінювання лазеру від дальності зондування з урахуванням зазначених умов представлена на графіку Рис.1.

\section{Література}

1. Черногор Л.О. Возможности применения лазерных исследований атмосферы зоны чрезвычайной ситуации/ Л.О. Черногор, А.С. Рашкевич// Восточно-Европейский журнал передовых технологий.- 2011. - 5/9 (53). С. 10 - 14.

2. Тюрін С.В. Дистанционный контроль содержания выбросов выхлопных газов авиационных двигателей лидарным методом/ С.В.Тюрін, А.А.Никишов, В.А.Романюк// Авіаційно-космічна техніка і технологія. Збірка наукових праць. - X: Національний аерокосмічний університет "XAl». - 2000. - Вип.21. - С. 19 - 21.

3. Набиев Ш.Ш. Современные тенденции развития методов дистанционного обнаружения радиоактивных и высокотоксичных веществ / Ш.Ш. Набиев // Вестник РАЕН. Физика. - 2012. - Вып. 1. - С. 14 - 25.

4. Межерис, Р.М. Лазерное дистанционное зондирование / Р. Межерис; Пер. с англ. И. Г. Городецкого, В. В. Филюшкина; Под ред. А. Б. Карасева. - М.: Мир, 1987. - 550 с.

5. Защита окружающей среды при авиатранспортных процессах / Под ред. Ененкова В.Г., 2-е изд. М., Транспорт, 1986. - 198 с.

6. Лазерный контроль атмосферы. под редакцией Э.Д. Хинкли. М.: Мир, 1979. 386 с.

7. Зуев В.Е. Дистанционное оптическое зондирование атмосферы/ В.Е. Зуев, В.В. Зуев// С. -П.: Гидрометеоиздат, 1992. - 212 с.

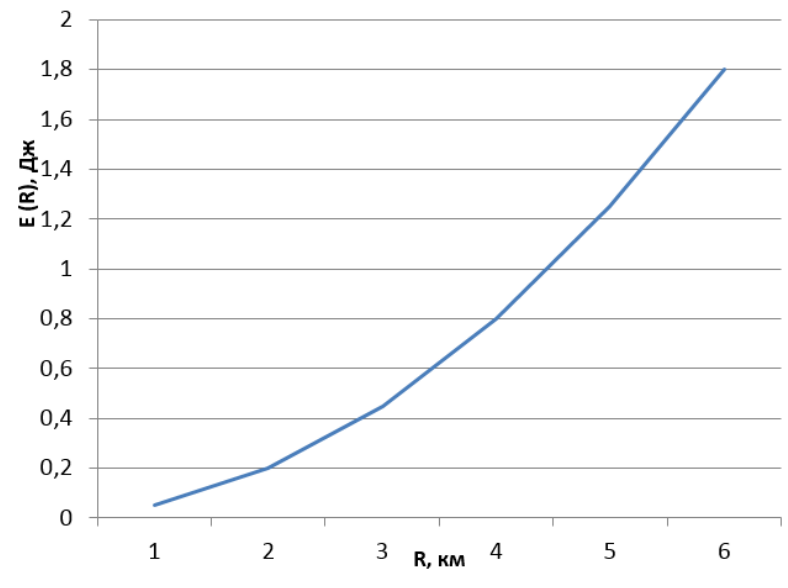

Рис.1. Залежність енергії випромінювання лазеру від дальності зондування.

Висновки. Аналіз графіка показує, що залежність енергії випромінювання від дальності зондування носить нелінійний характер.

Енергії сучасних зразків лазерів достатньо для контролю повітряного простору в районах, які знаходяться на відстанях, що забезпечують мінімальний негативний вплив на здоров'я людей, діяльність яких пов'язана з необхідністю працювати в місцях скупчення автомобілів.

\section{Reference}

1. Chernogor, L.O. (2011) 'Vozmozhnosti primeneniya lazernyih issledovaniy atmosferyi zonyi chrezvyichaynoy situatsii', Vostochno-Evropeyskiy zhurnal peredovyih tehnologiy, (5/9(53)), pp. 10-14.

2. Tyurin, S.V., Nikishov, A.A. and Romanyuk, V.A. (2000) 'Distantsionnyiy kontrol soderzhaniya vyibrosov vyihlopnyih gazov aviatsionnyih dvigateley lidarnyim metodom', in Aviatsiynokosmschna tehnika i tehnologiya. Zbirka naukovih prats. Kharkiv: National Aerospace University H.E. Zhukovsky 'Kharkiv Aviation Institute', pp. 19 - 21.

3. Nabiev, Sh.Sh. (2012) 'Sovremennyie tendentsii razvitiya metodov dis-tantsionnogo obnaruzheniya radioaktivnyih i vyisokotoksichnyih veschestv', Vestnik RAEN. Fizika, (1), pp. 14 - 25.

4. Mejeris, R. M. (1987) Laser remote sensing. Moscow. Mir. p. 550

5. Enenkova, V. G. (ed.) (1986) Zaschita okruzhayuschey sredyi pri avia-transportnyih protsessah. 2nd edn. Moscow: Transport. p. 198

6. Hinkli, E. D. (ed.) (1979) Lazernyiy kontrol atmosfery. Moscow: Mir. p. 416.

7. Zuev, V. E. and Zuev, V. V. (1992) Distantsionnoe opticheskoe zondirovanie atmosfery. Saint Petersburg: Gidrometeoizdat. p. 231. 


\title{
Аннотация
}

\section{Оценка энергетических характеристик квантово-оптических средств контроля содержания выбросов выхлопных газов автомобилей}

\author{
В.А. Романюк, С.А. Стародубцев, А.А. Савін, И.А. Черепнев
}

Проведен анализ теоретических основ лазерных измерений состава воздушной среды и возможности его применения в чрезвычайных ситуациях, вызванных выбросами в большом количестве загрязняющих газов, аэрозолей и микрочастиц дизельными двигателями, двигателями внутреннего сгорания автомобильного транспорта. Предложен метод решения задачи оперативного мониторинга состава газов примесей и аэрозолей в зоне контроля применением единого комплекса лазерной измерительной аппаратуры.

Наиболее перспективным методом диагностики загрязнений воздуха являются дистанционные методы зондирования. Среди дистанционных методов особое место занимают лазерные методы. Одним из самых эфффективных средств дистанционного мониторинга степени загрязнения окружающей среды являются лазерные мониторы, называемые также как лидары (по аналогии с радарами).

Методы зондирования делятся, в зависимости от способа получения информации на: активные при этом объекты окружающей среды зондуються электромагнитным излучением и пассивные, информация получается путем регистрации результата взаимодействия излучения природных источников или собственное излучение анализируемых примесей.

В статье рассмотрена возможность применения лазерных средств для оперативного контроля степени загрязненности окружающего воздуха выхлопами автомобильных двигателей. Приведенные оценки энергетических параметров лидара для выявления типичных загрязняющих компонентов.

Ключевые слова: лазер, атмосфера, оперативный мониторине.

\section{Abstract \\ Evaluation of energy characteristics of quantum optical means for controling the emissions of car exhaust gases}

\section{V.A. Romanyuk, S.A. Starodubtsev, A.A. Savin, I.A. Cherepnev}

The analysis of the theoretical foundations of laser measurements of the composition of the air and the possibility of its use in emergency situations caused by emissions of a large number of polluting gases, aerosols and microparticles by diesel engines, internal combustion engines of automobile transport is carried out. A method for solving the problem of operational monitoring of the gas composition of impurities and aerosols in the control zone using a single complex of laser measuring equipment is proposed.

The most promising method for diagnosing air pollution is remote sensing methods. Among remote methods, laser methods occupy a special place. One of the most effective means of remote monitoring of the degree of environmental pollution are laser monitors, also called lidars (similar to radars).

Sensing methods are divided, depending on the method of obtaining information into: active - while environmental objects are probed with electromagnetic radiation and passive, information is obtained by recording the result of the interaction of radiation from natural sources or the own radiation of the analyzed impurities.

The article considers the possibility of using laser tools for the operational control of the degree of environmental pollution by exhausts of automobile engines. The given estimates of the energy parameters of the lidar to identify typical polluting components.

Keywords: laser, atmosphere, operational monitoring.

Бібліографічне посилання/ Bibliography citation: Harvard

Romanyuk V., Starodubtsev S., Savin A., and Cherepnev I. (2019). Evaluation of energy characteristics of quantum optical means for controling the emissions of car exhaust gases. Engineering of nature management, (4(14), pp. $57-61$.

Подано до редакції / Received: 11.11.2019 